Lofland, Lyn $\mathrm{H}$. 1978 The Craft of Dying. Beverly Hills: Sage Publications, Inc.

Mauksch, Hans

1975 "The Organization Context of Dying." in Elizabeth Kubler Ross (ed.) Death: The Final Stage of Growth. Englewood Cliffs, N.J.: Prentice-Hall

Sagarin, Edward

1969 Odd Man In: Societies of Deviants in America. New York: Quadrangle Press.

Stoddard, Sandol

1978 The Hospice Movement: A Better Way of Caring for the Dying New York: Vintage Books.

\section{SOCIOLOGY AND LITERATURE: \\ THE DRAMATIZATION OF AN \\ EDUCATIONAL EXPERIENCE}

\author{
Nicholas Ch. Tatsis \\ State University of New York \\ Oneonta
}

\section{THE SETTING}

The news put me in a state of euphoria. After five years of constant preoccupation with sociological formalities, I happily seized the opportunity to teach a course in "Sociology Through Literature." A few faculty members, classicists by conviction, were very enthusiastic about seeing their Renaissance conception of the discipline being realized within their own intellectnal territory. The rest of my colleagues did not seem to notice the humanistic deviation in the curriculum. With all due respect, was amazed by their indifference. Sociology through literature? In many departments around the country, the issue would have generated ideological warfare. When one tries desperately for decades to gain scientific respectability, it is unlikely that one would allow literary nonsense to interrupt the work of theory construction. The edifice of sociology could not afford any longer romantic forms of appearance, even as an aesthetic (what a word!) possibility. The elaborate schemes of our positivistic rationale succeeded in bringing us status that should not be lost in pedagogical experimentation. Whatever its educational merits may be it would be unwise to substitute literature for the plethora of sacred material offered ceremoniously by the functionaries in the Comtean church of reason.

So the argument runs, and so most sociologists go around performing the ex officio duties of an authoritative professionalism. That is why I was surprised by my colleagues' apathy. Since the expected doctrinal confrontation did not occur, I started wondering about the state of our field. I knew from that forgotten thinker Pareto that if the guardians with their protective 
powers were in eclipse, something must have gone wrong. What was it? Had the lions of the established theoretical order lost control of the situation? Had the meaning-hunting foxes of the subjectivist opposition returned once again to disturb the equilibrium of the imperial system of grand theorists? Or had we arrived at the period of crisis prophesied by Gouldner? I did not spend much time reflecting on the eschatological issues, however, because the idea of the new course had become an obsession in my otherwise routine academic life. I am inclined to believe that the excitement was justified on the basis that I had managed to break through the well-protected gates of modern scientism. How often has anyone the chance these days to let such a mentality of liberation provoke the sociological imagination?

\section{THE CAST AND THE DIRECTOR}

At any rate, I projected a format for the course and started the necessary preparations to carry it out. Much to my astonishment, a good number of students showed up. It was an interesting group of young men and women, the brave new world, determined to experiment with types of inquiry outside the wasteland of conventional sociological wisdom. Exploring possibilities for understanding has always been a task seriously undertaken by minds not yet sterilized by scholasticism. The students represented various backgrounds that comprised a good sample of American society, albeit at the middle and lower levels of its economic structure. It is rather impossible to find patricians in state universities. But, after all, in terms of intellectual capacities, class distinctions are absolutely preposterous. You do not have to be a Marxist to realize that mental castration was never a prerogative exclusively of plebeians. On the contrary, the lack of nobility creates often a sense of the real, a life communion, which is unusually powerful in its inflamatory dynamics. This was the main advantage of our scholarly group. Its attitudes disclosed a clear-cut picture of our time's world-view. As the operation verstehen started enveloping us through masterpieces of world literature, the dramatic forms of logos touched the students' sensitivity and their reactions became the best possible indicators for the state of modern man. Whenever it reached their hearts and minds, the drama of social reality created pathos which was channeled into stormy conversations. Thus, in an atmosphere reminiscent of Platonic dialogues we overcame the meaninglessness that dominates the ideas of contemporary thinkers, and we illuminated many aspects of social relationships.

I should point out that in the process of discussion we faced various problems and, of course, I never hesitated for a moment to accept the severe confinements of sociological explanation. Nonetheless, I remarked, we all continue our efforts consciously aware that the fulfillment of a scholar is analogous to his naiveté Did not a great poet warn us that our achievements still remain a "perpetual possibility in the world of speculation"? I should also mention here that in the juxtaposition of literary and sociological directions, an unavoidable comparison took place. Not so much among the students, as (primarily) within my own intellectual conscience. This apparently absurd parallelism followed as a consequence of the modus operandi, for we had already transcended the mundane science into its art form. Despite my philosophical discomfort, it offered some interesting outcomes. It embarrassed me to witness Pirandello winning the battle over Goffman's dramaturgical exercises; Proust's psychological realism making the interactionists look quite unsophisticated; Beckett eliminating any chances for a sociology of the absurd; Dostoevksy competing successfully with the anomie theorists; Kafka offering the better account of bureaucracy; Balzac's acute vision ridiculing the senseless stratification studies, and so on. This list could be extended so as to cover almost all categories of sociological reasoning. The few exceptions are to be found either in the grandiose, holistic schematizations or in certain myopic, empiricist mathematizations which, needless to say, have never had any significant correspondence with the real world.

The embarrassment from this comparative perspective caused moments of critical reflection. What was so forcefully coming out of it became a terrifying nightmare. All of us are naive enough to look upon literary figures and see ourselves in an evolutionary manner. I personally experienced a disenchantment of a Spenglerian order that brought about a tendency for 
healthy reorientation. The lesson taken from literature in this course should have been our prime concern long ago. Why can't we make some sense in a similar fashion? What forced us to be disinterested spectators? Why are we still unable to project any human imperatives? Why is our knowledge so limited? Why can't we convince anybody? These questions are unanswered like most prayers to the gods of any kind. But the 'scientific' issues notwithstanding, literature provided me with some lessons about the problems of the rest of the world. It is time to go back and examine those problems under the light of their theatrical setting. There, in three tragic acts ritualistically staged, we might be able to unmask the heroes or anti-heroes who perform in them. Reductio ad absurdum? Yes. That is exactly what traditional sociology pretends to have avoided, is it not?

\section{THE PLAY}

\section{Act One: A-political}

The frame for the performance has been designated by now. All aspects of the forum are illuminated with impressionistic glares. I hope that my favorable treatment of idola theatri did not mislead anyone. This presentation was necessitated by a sympathy for their destiny, which is bound, in a Promethean condemnation, to our own existence. The plot must have been written by the same ingenious dialectic, and there is no sense in disputing the obvious.

Although it is hard to recall the beginning, our encounter with the irrational occurred unexpectedly. How can we possibly predict something that emanates ad infinitum from man's mind? It was or it seemed to be a routine lecture in political thinking. We read Alexander Solzhenitsyn's masterwork, 'One day in the life of Ivan Denisovich.' A total institution is symbolically given to show the fate of man in the pernicious pattern of twentieth century political reality. The story of human conditions in a concentration camp-it is so shocking in its agonizing description of the annihilation process as to transform the afflictive episodes into a mystic experience, a religious apocalypse. Due to the complexity of the subject, I decided to utilize our sociological resources and offered the students some historical background variegated with communist nostalgia from the promising days of the movement. We followed the course of action from the romantic Marx of 1844 all the way to the Georgian dictator. The class struggle of the world became an outcry of injustice, and men like Ivan Denisovich were portrayed as the 'noblest saints and martyrs' of a Hegelian theodicy. But this sensationalism was not enough to reach a desirable level of understanding. Some kind of theoretical elaboration was needed to bring history within the parameters of sociological explanation. We proceeded discussing the categories attached to the central notion of power. Naturally, we ended up building a Weberian castle that looked as authentic as any ideal formation would in intellectual projects. That sort of interference by Weber in Marxian affairs has always annoyed me to the point of questioning his capitalistic integrity. Then, I reversed my approach and began demolishing the conceptual 'house of power.' It was like a puzzle game. The central figure of our tale had mysteriously disappeared. Ivan Denisovich, the man who erected the whole power structure and owned it by the right of his cosmogony, was lost in the labyrinth of its reified dimensions. My effort brought no results. Ivan could not be found in the dark rooms of any political division, and the search was turning out to be ridiculously similar to Diogenes' cynical pursuit. He was ousted from his time; exiled for political expedience; ostracised to silence the anti-logos; banished as a historical nemesis. In the most paradoxical distortion of Gorky's play, Ivan became one among 'The Enemies' of the people, that is, an enemy of himself. A metamorphosis engineered by the system which aimed originally at the totality of man-the Marxian antithesis par excellence. If the theoreticians of revolution had known about Ivan's adventures, there is no doubt that they would have been more hesitant to trust negation in the dialectical process. Unfortunately, they never guessed the monstrous potentialities underlying its unlimited force.

This was my monologue more or less, when I realized that the students showed no sign of emotion, anxiety, or even curiosity. 
I suppose alienated individuals do not worry much about the fate of whatever lies beyond the horizon of their life-world. After a momentary reaction, Ivan Denisovich's ghost was left alone in the icy Siberian desert helpless amidst the Archipelago's raging waves of terror. This was an attitude which I could not possibly tolerate. I had to fight back and challenge on logical grounds the political insensitivity of the students. Based upon the central idea of Athenian democracy, that apathetic citizens are not simply useless but dangerous as well, my argumentation attacked the students' unconcern by showing the risks they are subjected to as a result of their dreadful disposition. After a while, it seemed again that I was talking to a deaf audience. It became clear to me that the story of Ivan Denisovich was far beyond their range of comprehension. Unrelated to any experience they have had, the event remained an invented theme from fiction. One of the most ominous realities in recent history was for them 'unreal.' What can anyone do when 'unreal' is everything that escapes the empirical immediacy and does not fit their projected categories of a spatio-temporal determination? There is nothing, I guess, but to be depressed by the modern predicament. The mistake may be that we all try to fight the phenomenon on logical grounds as I did. Explanations can always be given and, right or wrong, they may generate some sympathy. However, this is an inadequate way of solving the problem. One could easily arrive at interpetation through convincing syllogisms, but what is the possibility of making them relevant to minds alien to anything distant from the 'here and now' of parochialism? Assured by the panegyrists during the nation's bicentennial celebration, certain of their system's stability, guaranteed a balance of power after Watergate, secure under the auspices of a military-industrial complex, promised a better future by the political rhetoric, the students echoed logically enough the same youthful roman ticism that is so prevalent in American society. Under these circumstances, why should anybody be affected by descriptions of terror occurring in countries out our own 'safe' Lebensraum?

I am not writing a political essay to investigate these issues. I am only offering a commentary on educational matters. Despite all its obvious references, a theatrical presentation cannot exceed its stage limits. My readers as an audience might very well reflect upon the implications. of Act $I$ and follow a different thought process. I just expect that they at least would feel the need for catharsis.

\section{Act Two: A-social}

"But you, I beg you, check your wrath and scorn

For man needs help from every creature born."

Bertolt Brecht's lines sounded like the supplicatory words of a preacher. Any drama provokes sentiments of that sort and the German playwright expressed them even in his poetic creations. As Brecht himself once said, poetry always reflects private feelings about the world. It is a world abhorent for its unjust social conditions, the intolerance of which victimizes everyone. The verses of the great writer who lived stubbornly the dream of a socialist utopia overflow with sympathy for our problems in the inhuman world of capitalist societies.

"But you, I beg you, check your wrath and scorn

For man needs help from every creature born."

I assigned to my class Brecht's poem concerning the infanticide of a young, unwed mother named Marie Farrar. It had all the elements of a Euripidean tragedy: some new Medea killed her own child. It is a gloomy portrait of an outcast who, after the desperation of pregnancy at an early age, was forced to commit such a contemptuous act. Crime is not the word to describe the sin, for it has that legal connotation which reduces the sin to its formalistic aspects. Marie Farrar, "a minor, rachitic orphan," could not handle the situation and ended it with the same cruelty she had experienced in life. Death was the only outcome following in the sequence of events for the newborn: pain, poverty, stigmatization and suffering. Was not her decision of finality equally natural as all other possibilities? Hopeless and unable to think, Marie Farrar was led to the death defying road 
of self-destruction, the road that is depressingly open at the crossways of lost souls.

"But you, I beg you, check your wrath and scorn

For man needs help from every creature born."

Brecht's appeal did not leave my student indifferent this time. There must be, I suppose, certain limits to every kind of estrangement. When a problem disturbs the peace of a private world, no one can afford the luxury of detachment. Responding in turn to their paradoxical involvement, I decided that I should briefly discuss the matter. Infanticide, I said, is a deviation that draws the general interest of the public and its catholic need for passing judgment. Cases of similar importance are often the subject of intergenerational fascination. It seems that Durkheim was right in talking about the functional aspect of criminal behavior. Every group finds it necessary to reinforce its collective consciousness through an examination of past and present episodes. Searching for their own historical identity, however, groups commonly add another, distinctively separate dimension that expresses a novel perspective on life. This new perspective is taken to be a true one by their members whose belief in its authenticity becomes critically essential for the survival of the social unit. Then, provocative schemes emerge which are labeled by various innovative terms. One is tempted to admit that the world is a process in which such accepted neologisms and their meaningframeworks determine the course of action.

As if they wanted to support my sociological insights, the students demanded that the case of Marie Farrar must be brought to an imaginary court for retrial. Contemporary ideas had to be utilized in order to examine the incident from our point of view, to see it through another prism, and to judge 'objectively' its appalling facts. Her story should be presented in a synthetic form, so that the scenario would make visible the underlying issues to the theatergoers of modern times. The troubles of her life being not enough, poor Marie Farrar returned from oblivion as the expiatory victim in the confused system of moral imperatives.
It is the rule in social affairs to instrumentalize weakness for the sake of satisfying the masochistic tendencies of the social animal.

"But you, I beg you, check your wrath and scorn

For man needs help from every creature born."

The most impressive feature in reconstructing the happenings of Marie Farrar's case was a fatuous use of fashionable categories. She changed suddenly from a female to acquire the status of a person. With the magic of Protestant ethic she moved from the lower to the working class. Thus, she stopped being poor and became economically deprived. In order to prove the existence of a reformed criminal justice system, she turned into a juvenile delinquent. And for the advantages of our welfare state, she was promoted from a rachitic orphan to an underprivileged handicapped. One would have a hard time in recognizing her tragic figure under the masquerade of these senseless characterizations. If the word game were the only absurdity in their perception of events, the situation could have been at least tolerable. But this line of reasoning continued with more inane argumentation.

The students proceeded to see the act in the light of crime statistics. They talked about punishment and the chances for reform. The judicial process was viewed in relation to the economy. Marie Farrar, indiscriminately with all other criminals, was projected as a social problem to be solved within a network of bureaucratized officials. Beyond that, and when everything else had failed, the death penalty still remained. Society has the right to protect itself. For the achievement of maximum success, our rationalizations must not be restricted from sentimentality's force.

In their scrutiny of the crime's specific aspects, the students went through the details with the same curiosity that a criminologist would have shown. Was she educated? Did she get any psychiatric treatment? What are the consequences of pre-marital sex? Should we legalize abortion? Had any state agency offered its help? How about her financial situation? The whole examination period was spent on questions of that sort-unemotional and impersonal, without sympathy or compassion. The questions 
directly indicated a persistent attention to the well-being of the system. In the fervor of the students' analytical logic, the in dividual per se was forgotten as the non-essential part of the incident.

"But you, I beg you, check your wrath and scorn

For man needs help from every creature born."

My reaction did not match their naive excitement in the reenactment of the trial. 1 let the exchange of ideas go unhindered from serious challenge. What is the use? If Brecht's poetry left them completely unaffected, how could the dry forms of sociological thinking be more influential? In a way, it was preferable for me to remain a participant observer as their rationale revealed their strange outlook. They all played superman, and 1 cannot stand Nietzschean philosophy even as a parody. Although lacking any ideological context, they showed a perculiar attitude by identifying themselves with the established order. From that vantage point, one can discard easily any humanistic considerations. One can observe life comfortably as an abstraction, be disengaged from any commitments, and portray justice as a blindfolded lady like everyone else. What really upset me was that no one had questioned the lady's ability to see reality in all its complexity. Sartre's protest against the cruelty of analytical reasoning is not an existentialist trick after all. Most of the time, it is followed by humanly blindfolded people. Anyhow, 1 used the occasion to conclude the second act of this sociodrama. It was not difficult, I remarked, to understand their desire for blind objectivity. Why should I disagree? Speaking the truth may be dangerous, because "its light would offend some blind people." The irony of this line from Michelangelo caught a few students by surprise. They did not expect any criticism of their rational thought. Marie Farrar's case was utilized as an experiment, I said, and it helped the release of our impulses. Conservatism is only a small part of the issue at hand. Logic can justify it sometimes. What it cannot legitimize, however, is the elimination of its human prerequisites. For the record, 1 commented, Brecht informed us that Marie Farrar had committed suicide in prison.
One needed not to talk about death penalties. People are quite often better judges of themselves, and do not usually beg for help like the poets.

\section{Act Three: A-human}

The last act took place at the end of the course. There is no symbolism attached to this finale. The triadic form and its composition are purely coincidental. Literary ingenuity is often unable to compete with reality's insuperable creations.

My students had to write a typical undergraduate paper. They started visiting my office to confer with me upon their planned projects. Although the pieces they had selected were primarily from American writers, a couple of exceptions representing European realism-Zola, Tolstoy-made me very happy indeed. We went through the stories together, and I tried to help them by compiling ideas significant enough for a meaningful sociological theme.

One afternoon, I made an appointment with a student who participated infrequently during my seminar type discussions in the class. She used to sit quietly at the back of the lecture hall like a distant but attentive watcher of a strange ritual. While keeping notes all the time, she had never taken an active part in our debates. Ms. X, that slim, shy girl of Oriental extraction moved into my room holding a small volume in her hands. It was a collection of poems of religious inspiration by a writer unknown to me. Requesting an evaluation of her topic, she smiled politely and waited in repose for the critique. I carefully read a number of the poems. Despite the formality of the situation, I found it extremely difficult to keep my puzzlement, if not my disapproval, hidden from her. The poet's lines showed a naive conception of faith, and a sort of fanaticism that appeared unattractive to say the least. God's interest in human affairs was presented in a peculiarly deterministic set of power relationships. Exotic creatures accompanied ordinary people directing their actions in the mundane undertakings of everyday life. In order to show this dogmatic imposition of divine will, the poet described a dream world of sublime elements. 
Angels flew around mixing with the crowd and they seemed to have an emotional involvement in its rather trivial business. Although the flight looked prearranged, good and evil were struggling constantly in the arena of secular issues. Kierkergaard's 'either/or' philosophy must be mistaken. The heavenly guards are omnipresent to regulate with imperious tenacity every decision-making process. In brief, the picture painted by the versifier was as bizarre as the surrealistic murals of Salvador Dali.

$I$ did not want to offend Ms. $X$, but my temptation in finding out her religious affiliation had become irresistible. Without any reservations, she identified herself as an active member of the Jesus movement. (Out of respect for her privacy, I had better not reveal the particular sect.) After that direct reference to the collective spirits, she went on to elucidate the importance of religion in her life, the powerful impact of beliefs, and the harmony she had managed to achieve by balancing dogmatic fundamentalism and scientific thought. I was delighted with her last comment. My suspicion that Comte's progressive stages of human knowledge were purely fictitious appeared to be justified. The "New Christianity" has never reached the "high' level of science, because it has never abandoned its theological essence. With a tendency for innuendoes, common among intellectualizing individuals, I brought to mind the ideas of $M$. Heidegger: "Historians and philologists, by virture of a prejudice which modern rationalism adopted from Platonism, imagine that mythos was destroyed by logos. But nothing religious is ever destroyed by logic; it is destroyed only by the God's withdrawal."

The moments of my reflective silence encouraged Ms. X to continue her presentation. She must have been accustomed to a certain style of catechizing, for her voice echoed by now a Pascalian logic of the heart.' Religion, she said, lifted her up from the anonymity of the crowd and showed her the meaning of the world. Of course, this meaning was expressed best by a contemporary apostle, for whom she was ready to sacrifice herself. Every one in her group was willing to do the same. The true realization of a spiritual entity can come only through immolation. The members of the movement had a similar passion for fulfillment, and their actions were mirroring a state of existence that differentiated them from the outsiders. She generated such a nostalgic mood for her comrades that I responded spontaneously by quoting Ezra Pound: "I am homesick after my own kind of people."

Then, I laughed at my impetuous remark. This unconscious recollection of adages from Fascist ideologues like Pound and Heidegger struck me as unfitting in the peaceful hours of the late afternoon. It was all a kind of romanticism totally foreign to my personality. What had happened to me? Had Ms. X succeeded in changing my attitudes? I almost forgot the purpose of her visit. Trying to recover from the indoctrination session, I wrestled with the suffocating atmosphere of religiosity she had created. Sociologists, I confessed to her, are demonic beings. They would never save their souls, because their thoughts constituted the primordial sin of disbelief. They want to know while ignoring the aetiology of their desire for knowing. To paraphrase Tennessee Williams, they are like kids attempting to spell the word 'GOD' without every learning the alphabet. They will never be forgiven for selling naive improvisations when they are demythologizing bibles. However, they otherwise behave like any human creature on earth. Since I am myself a member of the same caste, I would be willing to let her write on the religious poems on the assumption that the angels must stop their busy schedule. No one is against literary allegories, but academics ought to be interested in real people. I explained to her that my compromise should not be taken as favoritism. I simply am inclined to be lenient toward the poets. Unbelievable as it may sound, my model of sympathy originated in Marx. The Red Doctor had given clemency to $H$. Heine and did not condemn the nonsense of his supposedly socialistic papers. The philosopher is obligated by the nature of his creative work to respect the artist. It is an idea that has been forgotten on all sides of the Marxist spectrum ever since.

Unexpectedly, Ms. X refused to accept my compromise. Her eyes burned with an animosity she could not control. This brought about a tension which I have no desire to bear anymore. After all, I was unable to understand why she distrusted me so 
much. I have given my word to treat her without bias and she had no reason for doubting the proposed compromise. Does the absence of religious norms create agnostic individuals with no decency? Such haughty behavior from Ms. X was going too far. $I$ looked at her straight in the eyes and demanded that she must reveal the source of her skepticism of me. With an equal determination, she stood up, raised her hand, demonstratively pointed at me, and screamed in anger:

\section{- "Because you are a Jew"!}

The accusation paralyzed my senses. Incapable of reacting, I remained speechless for a few minutes, staring at this petite anti-Semite who had the audacity for such a prejudicial statement. Have you ever experienced a similar situation? Have you ever found yourself locked in a prison cell? Denounced, labeled, stigmatized, numbered, framed, marked? Have you ever seen the world as a stranger? Unwanted, rejected, excluded, detested, deprived? Have you? Then, you may empathize with my position-crushed by the immense force of hate.

What made me feel worse was the fact that $I$ am not a Jew. I am formally a Greek (by accident of birth) and a Christian (by state policy). But how do you go about disproving a non-existent social category? And when did proof of any kind change the course of life? 'Unreality' has unjustly won its battles most of the time. It is the same unreality which hunts potential victims around the globe in every inhumane way. Can anyone stop its frenetic drive for a bloody victory over all of us who are or are not Jews-the distinction is pure scholasticism for the millions of martyrs? Throughout history, the list of victims has been rewritten many times in the past, and it is constantly printed under various editors. Ideological introductions to any forthcoming edition can easily be found in prophetic thought. It is simply a practical task for a demagogue to select his next group for destruction.

Unwillingly, Ms. X led me to the same dilemma Peter faced in denying Jesus. Peter cried afterwards, but I cannot do that. To begin with, I do not want to do that. It would be beyond my power to carry the cross of guilt of such a denial. Sorry Ms. X, I am not going to give you that satisfaction. She faded away from my horizon. Realizing that there was no chance that I would betray myself, she left without notice. It was like a daydream. I checked the papers on the table. They looked depressingly unintelligible. I tried to finish the article I was reading before she came: "The decomposition of effects in Path analysis." I felt nausea and ran out of my office. The moon was dim like Ms. X's image; the campus quad deserted. Where were my students, my colleagues, my friends? Alone but unafraid, I whispered the lines for the second quartet of Eliot's elegy:

"I said to my soul, be still, and let the dark come upon you Which shall be the darkness of God. As, in the theatre, the lights are estinguished, for the scene to be changed." 